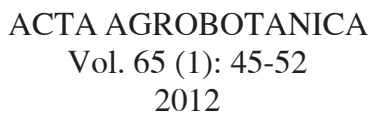

\title{
METEOROLOGICAL FACTORS AND AIRBORNE Rumex L. POLLEN CONCENTRATION IN LUBLIN
}

\author{
Krystyna Piotrowska \\ Department of Botany, University of Life Sciences, Akademicka 15, 20-095 Lublin, Poland \\ e-mail: krystyna.piotrowska@up.lublin.pl
}

Received: 12.12.2011

\begin{abstract}
The aim of the present study was to analyse the Rumex pollen season dynamics in Lublin in 2001-2010 and to find relationships between season parameters and meteorological conditions. This study was carried out by the volumetric method using a Lanzoni VPPS 2000 trap. The start and end dates of each season were determined based on the $98 \%$ method. The effects of meteorological factors on the Rumex pollen seasons were analysed by employing Spearman's correlation test. On average, the sorrel pollen season started on 13 May ( \pm 7 days), ended on 7 September ( \pm 6 days), and lasted nearly four months ( \pm 9 days). The highest pollen concentrations were recorded in June and July. A significantly negative correlation was found between season duration and Seasonal Pollen Index (SPI). During shorter pollen seasons, higher pollen counts were recorded. In all study years, the seasons were right-skewed. The pollen concentration was most strongly correlated with humidity and mean air temperature. The season parameters (onset, end, peak date, peak value, SPI value) were primarily dependent on air temperature before and during the pollen season.
\end{abstract}

Key words: aerobiology, sorrel pollen, seasonal variation, meteorological conditions

\section{INTRODUCTION}

According to Fijałk ow ski (1994), 13 species of the genus Rumex L. occur in the Lublin region. Common Rumex species include the following: $R$. acetosella L., R. acetosa L., R. thyrsiflorus Fingerh., R. hydrolapathum Hudson, R. crispus L., R. obtusifolius L., $R$. conglomeratus Murray, $R$. confertus Willd. Rarely or sporadically within this area are found: $R$. sanguineus L., $R$. maritimus L., $R$. palustris Sm., $R$. aquaticus L., $R$. ucrainicus Fisch. Sorrels have low habitat requirements. They occur on poor forest and field soils and grow on river banks, roadsides, meadows, and fallow land. The flowering period of individual Rumex species occurs at different times. Rumex acetosa flowers earliest, already in May. The other species start blooming in June or July and end in August or September (R u t k ow ski, 1998). Rumex pollen is collected by bees and they form large pollen loads (with an average weight of $7.9 \mathrm{mg}$ ) (Maurizio and Graf 1, 1969). The presence of Rumex pollen in honeys is evidence of bees' interest in this pollen (W a r a k o m s k a, 1997; Wróblew s ka, 2002).

The occurrence of numerous species in a given area and different flowering times are the most important reasons for the long Rumex pollen season. Flowering of individual species usually lasts two or three months (Rutkowski, 1998), but the atmospheric pollen season of this taxon can last more than four months (Weryszko-Chmielewska, 2006). During the summer period, pollinoses are associated primarily with the flowering of herbaceous plants which release large amounts of pollen into the atmosphere. It has been calculated that one Rumex acetosella flower produces more than 65000 pollen grains, while one plant more than 4 million (P i o t r o w s ka, 2008). Sorrel pollen can cause pollen allergy in sensitive people. The clinical importance of Rumex in Poland

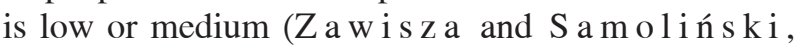
1998). Sorrel pollen is present in the air at the same time as Poaceae pollen grains that belong to the most important allergenic taxa in Poland. The time of the Rumex pollen season largely overlaps with the time of the pollen seasons of Plantago, Urtica, and Chenopodiaceae. In July and August, Rumex pollen is recorded simultaneously with pollen grains of Artemisia, while in May together with the pollen of Betula, Quercus, and Pinaceae (Weryszko-Chmielewska and Pi otrow ska, 2004). The simultaneous occurrence 
of airborne pollen of various taxa can have an adverse effect on allergic people, since pollen allergy is frequently associated with hypersensitivity to several allergens. Among people allergic to grass pollen, a positive reaction to Rumex allergens has been found in as many as $70 \%$ of them, which results from a cross reaction between allergens contained in the pollen of these plants (M a s ch and Geis sler, 1983).

The aim of the present study was to analyse the Rumex pollen seasons in the eastern Poland over a period of 10 years and to determine correlations between meteorological conditions, pollen concentrations, and the features of the pollen season.

\section{MATERIAL AND METHODS}

Rumex pollen monitoring was carried out in Lublin from 2001 to 2010. A Hirst - type trap, Lanzoni VPPS 2000 was applied. The sampler was placed on the flat roof of the building of University of Life Sciences in Lublin, $18 \mathrm{~m}$ above ground level (22.32'25' $\mathrm{E}$ and $51^{\circ} 14^{\prime} 37^{\prime \prime} \mathrm{N} ; 197 \mathrm{~m}$ a.s.1.). Pollen grains were identified and counted in four horizontal transects. Results were showed as the mean daily pollen counts per $1 \mathrm{~m}^{3}$ of air $\left(\mathrm{P} / \mathrm{m}^{3}\right)$. The pollen season was calculated using the $98 \%$ method (E m b e r $\mathrm{l}$ i n et al., 1994; S pieksma and Nikkels, 1998). The start of the season was determined as the date when $1 \%$ of the seasonal cumulative pollen count was trapped and the end of the season when the cumulative pollen count reached $99 \%$.

The Rumex pollen seasons analysis was conducted by means of the following descriptive statistics: arithmetic mean, minimum and maximum values, standard deviation (SD), and coefficient of variation (V\%). The skew coefficients were also calculated to define direction and asymmetry value. A positive value of this coefficient indicates a right skew, while a negative value means a left skew (W o łe k, 2006). The following weather parameters were chosen to estimate the meteorological data impact on Rumex pollen seasons: air temperature (average, minimum and maximum), relative air humidity, rainfall, cloud cover, and wind speed. The average monthly meteorological data (January-May) and mean weather conditions during the pollen season were analysed. The meteorological data origin from the Meteorological Observatory of the Meteorology and Climatology Department, the Maria Curie-Sklodowska University in Lublin. The Observatory was located at a distance of about $1.5 \mathrm{~km}$ from the pollen sampling site. The analysis of Spearman's rank order correlation was applied to determine relations between the particular meteorological factors and pollen season features.

\section{RESULTS}

The Rumex pollen seasons during the period 2001-2010 were characterized by high variability. The peak value and SPI belonged to the season parameters with the highest variability. The lowest coefficient of variation was found for the pollen season end date (Table 1). A positive correlation was found between the values of maximum concentration and SPI ( $r=0.9758$; $\mathrm{p}<0.01$ ). During the pollen season, several smaller peaks were also observed in addition to the maximum peak. Over the 10-year study period, average concentrations of sorrel pollen were the highest during the period from the middle of June until the middle of July (Fig. 1), but in the years 2004 and 2009 maximum pollen counts were recorded in the second half of July. Lower pollen concentrations were generally observed during longer seasons compared to shorter ones (Fig. 1). This observation was confirmed statistically, since a negative correlation was found between SPI and season duration $(r=-0.6667 ; \mathrm{p}<0.05)$.

In 2001-2010 the Rumex pollen seasons were right-skewed. A fairly quick increase in pollen concentration and a distinctly slower decrease were mostly observed. The coefficients of skewness were in the range of 1.5-2.5. The pre-peak period lasted on average 43 days, whereas the post-peak period 74 days.

Table 1.

Characteristics of the Rumex pollen season in Lublin, 2001-2010

\begin{tabular}{ccccccc}
\hline \multirow{2}{*}{ Statistics } & \multicolumn{3}{c}{ Pollen season } & & Peak & \multicolumn{2}{c}{ SPI } \\
\cline { 2 - 7 } & Start & End & Duration (days) & P/m & Date & Pollen sum \\
\hline Mean & 13.05 & 7.09 & 118 & 78 & 25.06 & 1520 \\
Min & 30.04 & 25.08 & 103 & 46 & 1.06 & 1033 \\
Max & 25.05 & 16.09 & 136 & 152 & 24.07 & 2114 \\
SD & 6.9 & 6.4 & 9.0 & 33.7 & 17.1 & 401.4 \\
V (\%) & 5.2 & 2.6 & 7.7 & 43.4 & 9.7 & 26.4 \\
\hline
\end{tabular}




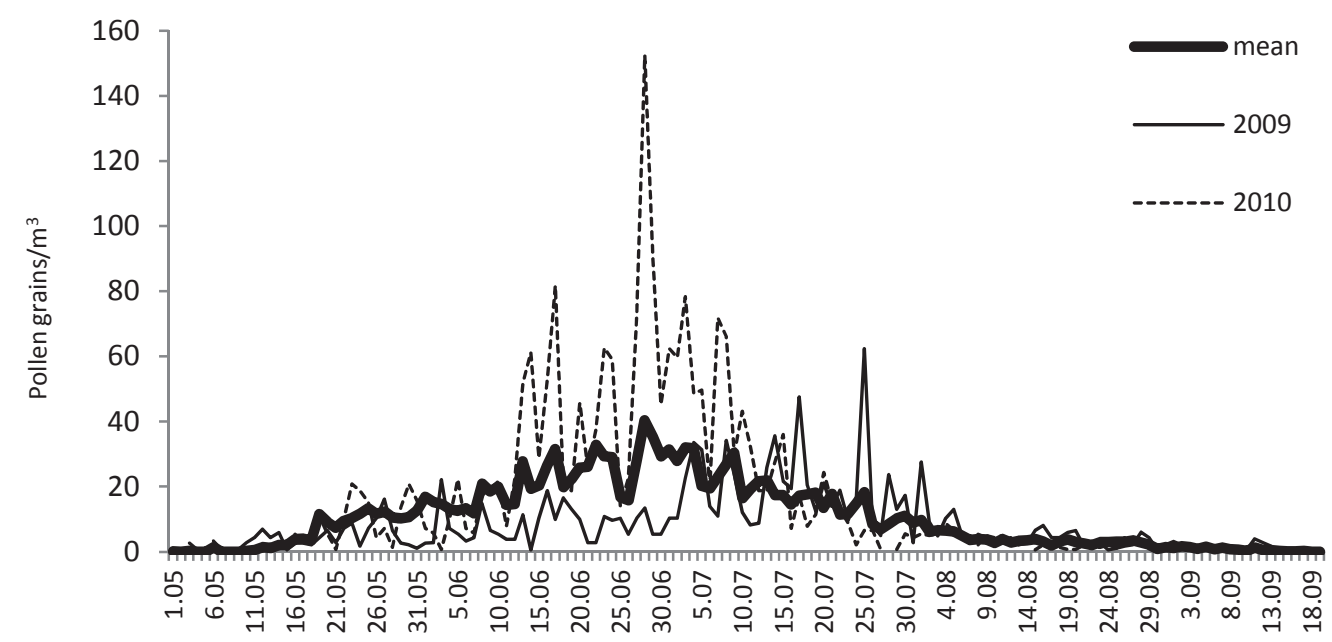

Fig. 1. The mean Rumex pollen count (2001-2010) and the selected years with the longest (2009) and the shortest (2010) pollen season.

During the sorrel pollen season in Lublin in 2001-2010, average air temperature was $18.8^{\circ} \mathrm{C}$. The season was the coldest in 2004 and the warmest in 2010. The highest relative air humidity was also obse- rved during the pollen season in 2010 . The highest rainfall was recorded in the years 2001 and 2009 (394.1 and $348 \mathrm{~mm}$, respectively), whereas rainfall was the lowest in 2008 (172.2 mm) (Fig. 2).

Table 2 .

Significant Spearman's correlations between Rumex pollen counts and meteorological factors in Lublin.

\begin{tabular}{lc}
\hline Meteorological factor & Spearman coefficient \\
\hline Average temperature & $0.1626 * *$ \\
Minimum temperature & $0.1297 * *$ \\
Maximum temperature & $0.0987 * *$ \\
Rainfall & $-0.1002 * *$ \\
Humidity & $-0.1858^{* *}$ \\
Cloud cover & $-0.0637 *$ \\
Wind speed & 0.0308 \\
\hline
\end{tabular}

Level of significance $* 0.05, * * 0.01$

The statistical analysis shows that there is a significant correlation between pollen concentration and most of the weather factors studied (Table 2). The highest correlations were observed for humidity (a negative correlation) and average air temperature (a positive correlation). High temperature promoted an increase in pollen concentration, while a rise in relative air humidity and rainfall caused a decrease in pollen concentration.

During the period 2001-2010, the Rumex pollen season in Lublin started on 13 May, on average. The earliest start of the season was recorded on 30 April in 2009, whereas the latest one on 25 May in 2005 (Table 1, Fig. 3). The early onset of the pollen season in 2009 was associated with high temperature in the month preceding pollen release. Maximum temperature in April 2009 was $17.0^{\circ} \mathrm{C}$, while in the other years it ranged $11.9^{\circ} \mathrm{C}-14.5^{\circ} \mathrm{C}$. The end of the Rumex pollen season was on average recorded on 7 September. The pollen season ended earliest (25 August) in 2010 which was one of the warmest years. The latest season end date (16 September) was related to low temperatures during the pollen season in 2004 (Figs 2, 4). This relationship was confirmed statistically (Tab. 3). On average, $R u$ mex pollen was present in the atmosphere of Lublin for almost 4 months; this period was the longest (136 days) in 2009 and the shortest (103 days) in 2010 (Table 1, Fig. 5). The maximum daily concentration of sorrel pollen ranged $46-152 \mathrm{P} / \mathrm{m}^{3}$ (Fig. 6). The date of maximum concentration greatly varied between years. The seasonal maximum occurred earliest on 1 June (the 152 nd day of the year, the 18th day of the season) in 2003, while the latest date was 24 July (the 205th day of the year, the 86th day of the season) in 2009 (Fig. 7). 
The Seasonal Pollen Index ranged 1033-2114 pollen grains, with its highest value in 2010 and the lowest one in 2004 (Fig. 8).

The statistical analysis showed that the onset of the Rumex pollen season depended on temperature at the beginning of March (a negative correlation) and on rainfall at the beginning of May (a positive correlation). The season end date was negatively correlated with air temperature in March, in the second ten-days period of May, and during the pollen season. The peak date was correlated with minimum temperature in February and maximum temperature in the second ten-days period of May. The peak value depended on wind speed, mean and maximum air temperature during the season as well as cloud cover at the beginning of March. Similar relationships were found for the SPI (Tab. 3).

A

Mean temperature

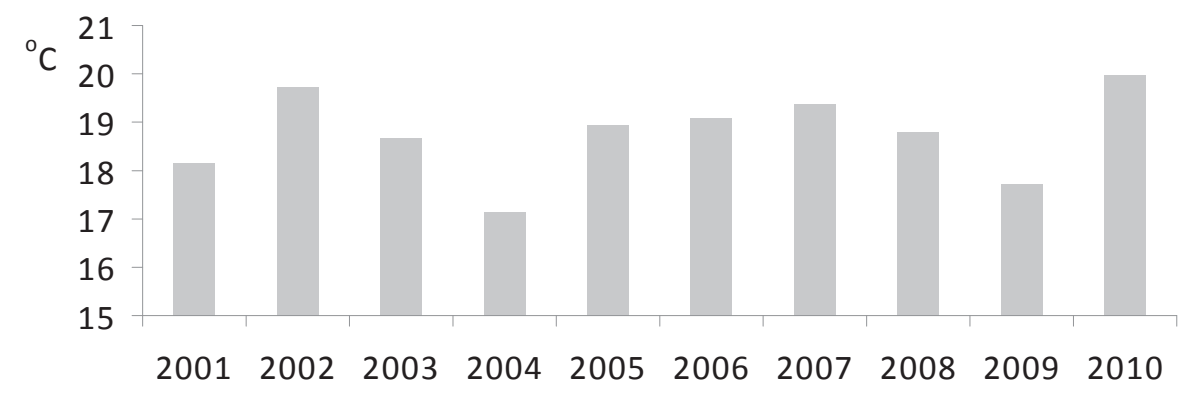

B

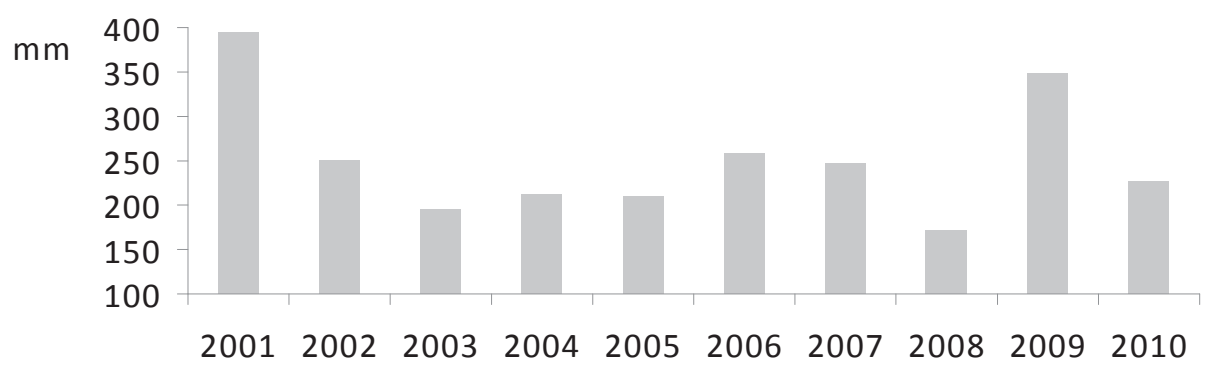

C

Humidity

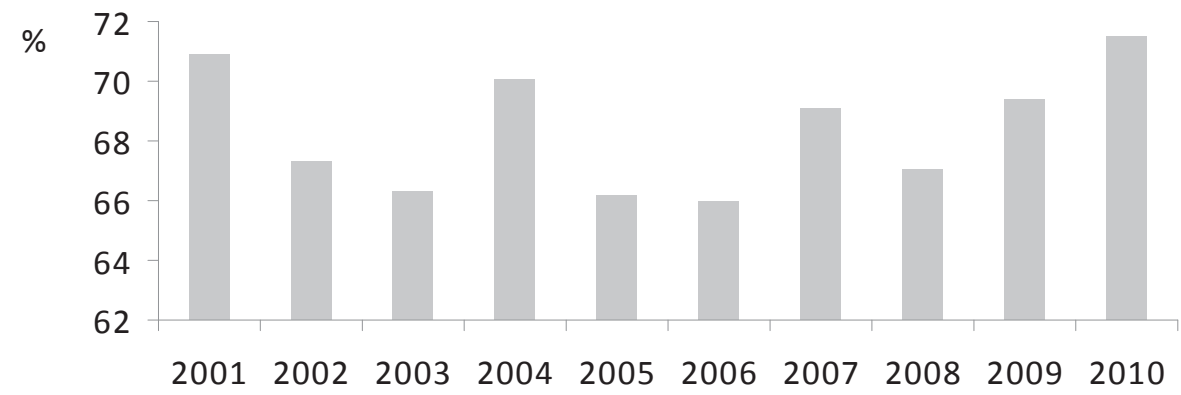

Fig. 2. Mean data of selected meteorological factors during the Rumex pollen season in Lublin, 2001-2010.

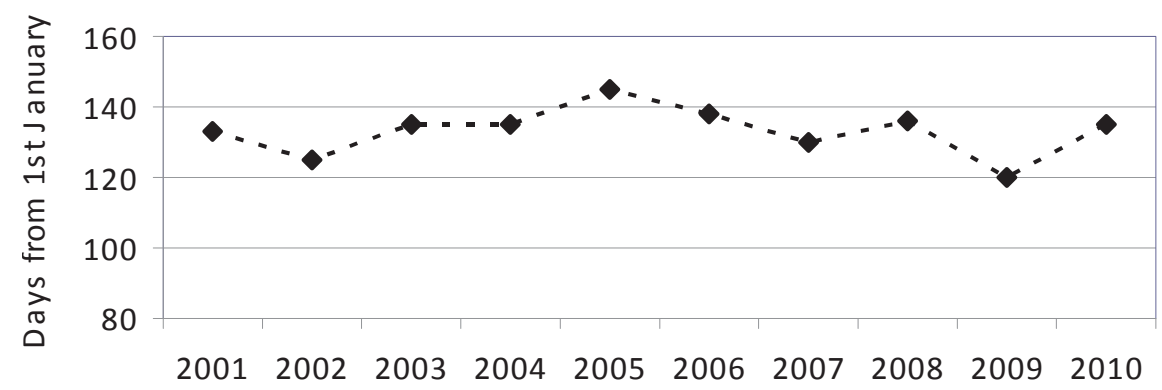

Fig. 3. The start of the Rumex pollen season in Lublin, 2001-2010. 


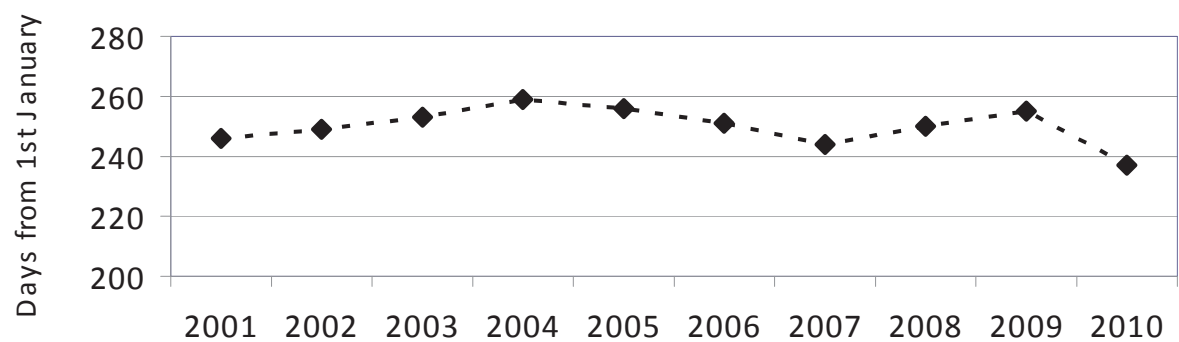

Fig. 4. The end of the Rumex pollen season in Lublin, 2001-2010.

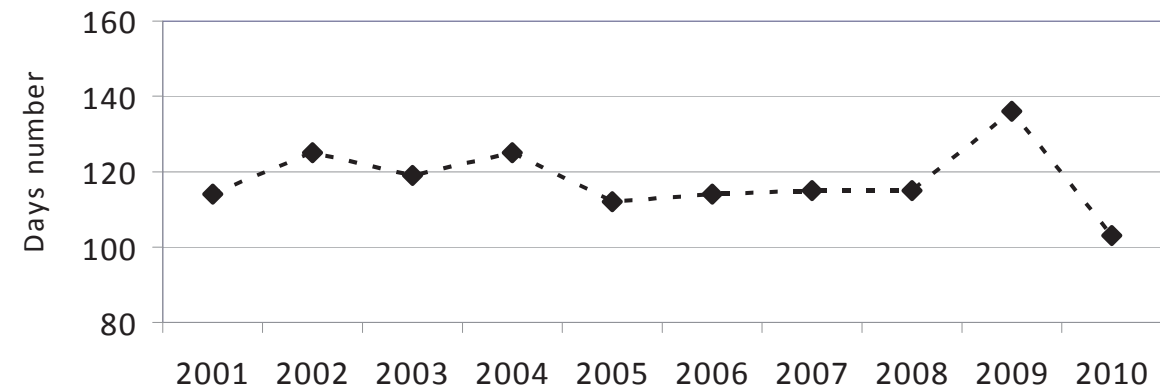

Fig. 5. The duration of the Rumex pollen season in Lublin, 2001-2010.

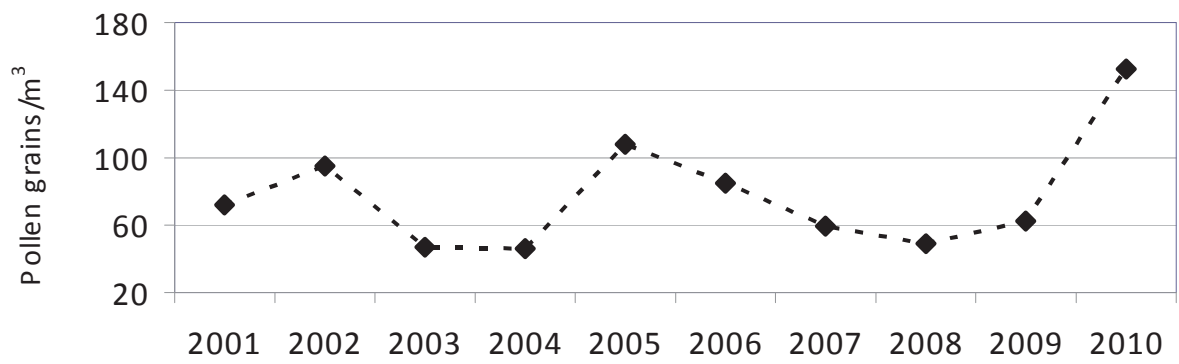

Fig. 6. The peak value of the Rumex pollen season in Lublin, 2001-2010.

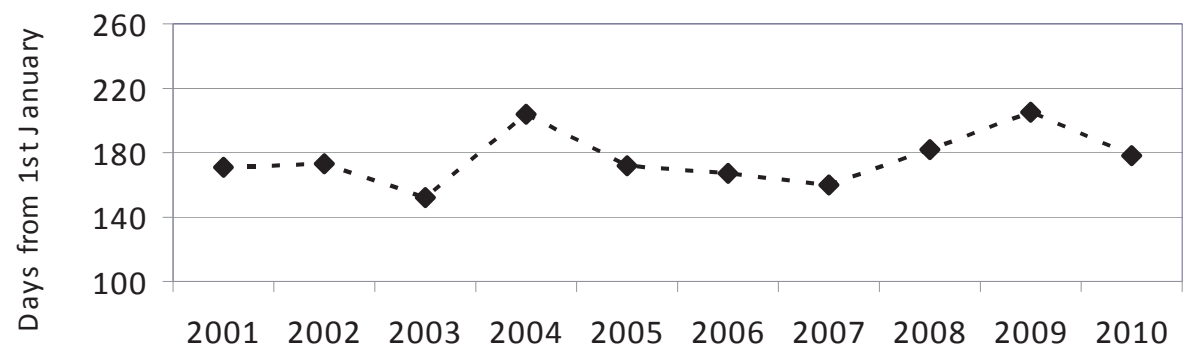

Fig. 7. The peak date of the Rumex pollen season in Lublin, 2001-2010.

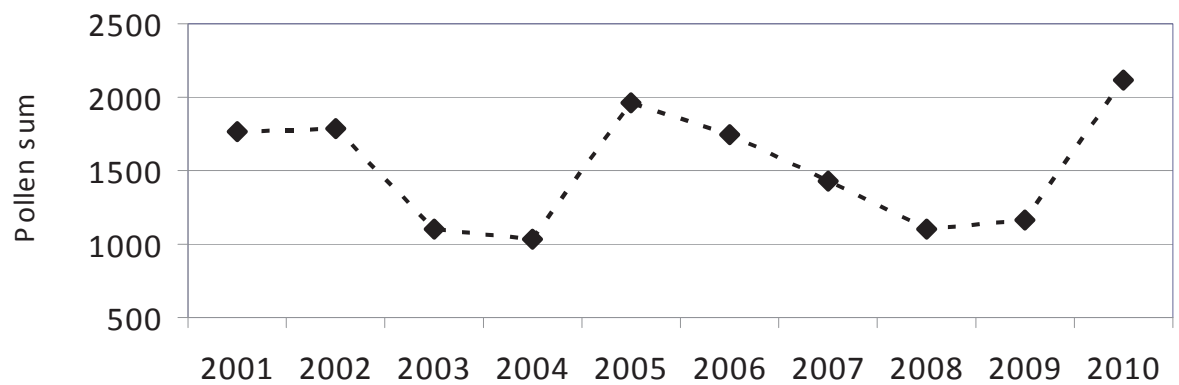

Fig. 8. The sum of Rumex pollen counts recorded during a season in Lublin, 2001-2010. 
Table 3 .

Significant Spearman's correlations between pollen season parameters and meteorological factors in Lublin (2001-2010)

Season parameter vs meteorological factor

Spearman coefficient

\section{Dependent variable: season start}

10-day mean daily average temperature days 61 - 70 from January 1 st

$-0.6933^{*}$

10-day mean daily minimum temperature days $61-70$ from January 1 st

$-0.6933^{*}$

10-day mean daily maximum temperature days $61-70$ from January 1 st

$-0.6565 *$

10-day mean daily rainfall days $121-130$ from January 1 st

$0.6462 *$

\section{Dependent variable: season end}

Mean daily average temperature during the Rumex pollen season

$-0.6848 *$

Mean daily minimum temperature during the Rumex pollen season

$-0.7256^{*}$

10 -day mean daily maximum temperature days $61-70$ from January $1 \mathrm{st}$

$-0.6970^{*}$

10-day mean daily average temperature days 131 - 140 from January 1st

$-0.8061 * *$

10-day mean daily minimum temperature days $131-140$ from January 1st

$-0.8061 * *$

10-day mean daily maximum temperature days 131 - 140 from January 1st

$-0.7091^{*}$

Mean March daily maximum temperature

$-0.6364^{*}$

Dependent variable: peak date

10-day mean daily maximum temperature days 131 - 140 from January 1 st

$-0.6606 *$

Mean February daily minimum temperature

$0.6848 *$

\section{Dependent variable: peak value}

Mean daily average temperature during the Rumex pollen season

$0.6848 *$

Mean daily maximum temperature during the Rumex pollen season

$0.6829 *$

Mean daily wind speed during the Rumex pollen season

$-0.7016^{*}$

10-day mean daily cloud cover days 61 - 70 from January 1 st

$-0.7576^{*}$

\section{Dependent variable: SPI value}

Mean daily average temperature during the Rumex pollen season

$0.7091 *$

Mean daily maximum temperature during the Rumex pollen season

$0.7134 *$

Mean daily wind speed during the Rumex pollen season

10-day mean daily relative humidity days $61-70$ from January 1 st

$-0.7078 *$

10-day mean daily cloud cover days 61 - 70 from January 1st

$-0.6727^{*}$

$-0.6848^{*}$

Level of significance $* 0.05, * * 0.01$

\section{DISSCUSION}

In the pollen calendar for Poland, the pollen seasons of Rumex, Poaceae, and Plantago belong to the longest ones (Weryszko-Chmielewska and Piotrowska, 2004; Pi otrowska, 2006; Weryszko-Chmielewska, 2006). The sorrel pollen season in Lublin in 2001-2010 lasted from 3.5 to 4.5 months. The longest seasons were accompanied by low values of the SPI, whereas during shorter seasons higher SPI values were observed. P u c (2006) found a similar relationship for Rumex pollen in Szczecin. Relative humidity and mean air temperature are independent variables that had the greatest effect on pollen concentration in Lublin. On the other hand, in Szczecin daily concentrations of Rumex pollen depended primarily on humidity, maximum temperature, and wind speed (P u c, 2006). A study conducted in Poznań over the period 1995-2005 shows that daily counts of Rumex pollen were strongly correlated with temperature (mean, maximum, and minimum), sun hours, and humidity (A l c á z a r et al. 2009).

The beginning of the Rumex pollen season in Lublin was predominantly recorded on various days of May, exceptionally at the end of April with favourable weather conditions. Similar observations were made in other cities of Poland (Werys zko-Chmielewska, 2006). The statistical analysis shows that in Lublin the pollen season started earlier when high temperatures were recorded at the beginning of March, whereas the season onset was the latest when there was rainfall at the beginning of May. The sorrel pollen season in Lublin usually ended in the first half of September and only in 2010 at the end of August. The pollen season was found to end earlier when it was accompanied by high temperatures. In other cities of Poland, the earliest season end date was recorded on 8 August (in Kraków) or in the middle of August (in 
Poznań and Wrocław) (W e r y s z k o - C h m i e le w s k a, 2006).

The study carried out in Lublin in the period 2001-2010 found the peak value to be higher under weaker wind conditions and at higher air temperature during the season. The highest daily concentration of Rumex pollen was recorded most frequently in June and slightly less frequently in July. In 2009, when the latest date of the seasonal maximum was recorded, there was a lot of rainfall; this may have contributed to the delay in the occurrence of the peak. However, this correlation was not confirmed statistically. The statistical analysis showed that the peak value was negatively correlated with maximum air temperature in May. A comparison of maximum Rumex pollen counts in 8 cities of Poland in 2001-2005 demonstrates that the highest concentrations occurred in Szczecin and Lublin, while the lowest ones in Wrocław and Kraków. The seasonal maximum occurred at different times; the earliest date was 10 May in Rzeszów in 2002 and the latest one 9 August in Szczecin in 2004. The maximum Rumex pollen concentrations were most frequently recorded in June or July (W e ry s z k o - Chmielewska, 2006). Likewise, in Poznań the highest sorrel pollen concentrations were most often recorded in June or July during the period 2005-2007 (R odríguez-R a jo et al. 2010).

In Lublin the SPI value increased when mean and maximum air temperature during the season were higher, whereas a decline in SPI was recorded under high wind speed conditions during the season as well as at high humidity and high cloud cover at the beginning of March. In 2001-2005, among the 8 cities in Poland included in the comparison, the highest annual counts of Rumex pollen were recorded in Lublin (W e ryszko-Chmielewska, 2006). But in 2011 the highest annual total of Rumex pollen occurred in the northern part of Poland and the lowest ones in the southern part (Wrocław and Katowice) (W e r y s z k o- Chmielewska et al. 2011).

\section{CONCLUSIONS}

Rumex pollen was recorded in the atmosphere of Lublin from the end of April until the middle of September, with the highest concentrations in June and July.

During shorter pollen seasons, higher pollen counts were observed.

The pollen counts in season was most strongly correlated with humidity and mean air temperature.

Air temperature belonged to the most important factors affecting particular features of the Rumex pollen season.

\section{Acknowledgements}

Research supported by Poland's Ministry of Science and Higher Education as part of the statutory activities of the Department of Botany, University of Life Sciences in Lublin.

\section{REFERENCES}

A lcázar P., Stach A., Nowak M., Galán C., 2009. Comparison of airborne herb pollen types in Cordoba (Southwestern Spain) and Poznań (Western Poland). Aerobiologia, 25: 55-63.

Emberlin, J., Jones, S., Bailey, J., Caulton, E., Corden, J., Dubbels, S., Evans, J., McDonagh, N., Millington, W., Mullins, J., Russe1, R. \& Spencer, T., 1994. Variation in the start of the grass pollen season at selected sites in the United Kingdom 1987-1992. Grana, 33: 94-99.

Felber F., Clot B., Leimgruber A., Spertini F., (Eds) 2003. Plantes, Pollen \& Allergies. Les Cahiers du Jardin botanique, Neuchâtel (in French).

Fijałkow ski D ., 1994. Flora roślin naczyniowych Lubelszczyzny. Lubelskie Towarzystwo Naukowe, Lublin (in Polish).

Maasch H.J., Geis sler W., 1983. In-vitro-Untersuchungen zur Allergen Bedeutung von Sauerampferpollen. Allergologie, 6: 10-12 (in German).

Maurizio A., Grafl I., 1969. Das Trachtpflanzenbuch. Ehrenwirth Verlag, München (in German).

Piotrowska K., 2006. Kalendarz pyłkowy dla Lublina, 1995-2000. / Pollen calendar for Lublin, 1995-2000. Acta Agrobot. 59, (1): 529-538 (in Polish).

P i ot row ska K., 2008. Pollen production in selected species of anemophilous plants. Acta Agrobot. 61 (1): 41-52.

Puc M., 2006. Meteorological factors and pollen season dynamics of selected herbaceous plants in Szczecin, 20042008. Acta Agrobot. 62 (2): 97-109.

Rodríguez-Rajo J.F., Fdez-Sevilla D., Stach A., Jato V., 2010. Assessment between pollen seasons in areas with different urbanization level related to local vegetation sources and differences in allergen exposure. Aerobiologia, 26: 1-14.

Rutkowski L., 1998. Klucz do oznaczania roślin naczyniowych Polski niżowej. Wyd. Nauk. PWN, Warszawa (in Polish).

Spieksma, F.Th.M., Nikkels, A.H., 1998. Airborne grass pollen in Leiden, The Netherlands: annual variations and trends in quantities and season starts over 26 years. Aerobiologia, 14, 347-358.

Warakomska Z., 1997. Obraz pyłkowy wielokwiatowych miodów Lubelszczyzny. / Pollen spectrum of multifloral honeys of Lublin region. Mat. I Ogólnopol. Konf. Nauk. „Biologia kwitnienia, nektarowania i zapylania roślin”, Lublin, 13-14 listopada 1997: 170-177 (in Polish). 
Weryszko-Chmielewska E., Piotrowska K., 2004. Airborne pollen calendar of Lublin, Poland. Ann. Agric. Environ. Med. 11: 91-97.

Weryszko-Chmielewska E. (Ed), 2006. Pyłek roślin w aeroplanktonie różnych regionów Polski. Wyd. Akademii Medycznej w Lublinie, Lublin (in Polish).

Weryszko-Chmielewska E., Piotrowska K., Malkiewicz M., Klaczak K., Lipiec A., Rapiejko P., Staroń K., Chłopek K., Dąbrowska-Zapart K., Puc M., Kiziewicz B., Gajo B., Kalinowska E., 2011. Analiza sezonów pyłkowych szczawiu w wybranych miastach Polski w 2011 roku. / The analysis of sorrel pollen seasons in selected Polish cities in 2011. Alergoprofil, 7 (4): 21-24 (in Polish).

Wodehouse R.P., 1971. Hayfever plants. Their appearance, distribution, time of flowering, and their role in hayfever. Hafner Publishing Company, New York.

Wołek J., 2006. Wprowadzenie do statystyki dla biologów. Wydawnictwo Naukowe Akademii Pedagogicznej, Kraków (in Polish).

Wróblew ska A., 2002. Obraz pyłkowy miodów niektórych gmin Podlasia. / Pollen spectrum of honeys of some Podlasie districts. Ann. UMCS, Sect. EEE X: 113-121 (in Polish).

Zawisza E., Samoliński B. (Eds), 1998. Choroby alergiczne. Wydawnictwo Lekarskie PZWL, Warszawa (in Polish).

\section{Czynniki meteorologiczne a stężenie pyłku Rumex L. w powietrzu Lublina}

\section{Streszczenie}

Celem badań była analiza dynamiki sezonów pyłkowych Rumex w Lublinie w latach 2001-2010 oraz znalezienie zależności między parametrami sezonu a warunkami meteorologicznymi. Badania prowadzono metoda wolumetryczną przy użyciu aparatu Lanzoni VPPS 2000. Początek i koniec sezonu ustalono w oparciu o metodę 98\%. Wpływ czynników meteorologicznych na sezony pyłkowe szczawiu analizowano stosując test korelacji Spearmana. Sezon pyłkowy szczawiu rozpoczynał się średnio 13.05 ( \pm 7 dni), kończył 7.09 ( \pm 6 dni) i trwał prawie cztery miesiące ( \pm 9 dni). Najwyższe stężenia pyłku notowano w czerwcu i lipcu. Stwierdzono negatywną istotną statystycznie korelację między długością sezonu a wartością SPI. W czasie krótszych sezonów pyłkowych notowano wyższe sumy ziaren pyłku. We wszystkich latach badań sezony były prawostronnie asymetryczne. Stężenie ziaren pyłku szczawiu w sezonie było najsilniej skorelowane z wilgotnością i średnią temperaturą powietrza. Cechy sezonu (początek, koniec, data wartości maksymalnej, wartość maksymalna, SPI) uzależnione były przede wszystkim od temperatury powietrza przed lub w czasie sezonu pyłkowego. 